\title{
Fine-scale habitat selection of foraging bottlenose dolphins Tursiops truncatus near Clearwater, Florida
}

\author{
Mark C. Allen ${ }^{1, *}$, Andrew J. Read ${ }^{3}$, Jocelyn Gaudet ${ }^{2}$, Laela S. Sayigh ${ }^{1}$ \\ ${ }^{1}$ Department of Biological Sciences, and ${ }^{2}$ Department of Earth Sciences, University of North Carolina at Wilmington, \\ 601 S. College Road, Wilmington, North Carolina 28403, USA \\ ${ }^{3}$ Duke University Marine Laboratory, Nicholas School of the Environment, 135 Duke Marine Lab Road, \\ Beaufort, North Carolina 28516, USA
}

\begin{abstract}
Previous studies have proposed that seagrass habitats, by supporting diverse and abundant fish assemblages, are preferred by foraging dolphins in coastal systems. To test this hypothesis, we (1) examined the fine-scale behavior of bottlenose dolphins in relatively pristine and developed inshore sites near Clearwater Harbor, Florida, USA, and (2) used an otter trawl to sample potential fish prey in non-seagrass and seagrass habitats. In the pristine site, dolphins preferred dredged channel and spoil-island habitats, while least preferring shallow seagrass habitats. In the developed site, foraging dolphins preferred the natural channel habitat, but exhibited little further selection. Therefore, the hypothesis that dolphins prefer seagrass habitats while foraging was rejected. Feeding frequency was significantly associated with diel state, with foraging peaking at dawn and decreasing throughout the day. Dolphin group size was negatively correlated and nearest neighbor distance positively correlated with feeding frequency. Analysis of trawl data focused on the pinfish Lagodon rhomboides which dominates the diets of dolphins in west Florida. The relative abundance of pinfish was significantly greater and standard lengths significantly less in seagrass than in non-seagrass habitats. Dolphins therefore forage in non-seagrass habitats where fish prey is both larger and perhaps more available. Although seagrass habitats support greater abundance of smaller fishes, they also provide a structural refuge which obscures fishes both visually and possibly acoustically. Thus, the importance of seagrasses to the health of coastal dolphins is probably indirect, as seagrasses support fish populations on which dolphins rely.
\end{abstract}

KEY WORDS: Tursiops truncatus · Foraging strategy · Prey availability $\cdot$ Diel patterns $\cdot$ Pinfish Lagodon rhomboides

Resale or republication not permitted without written consent of the publisher

\section{INTRODUCTION}

The interactions between bottlenose dolphins Tursiops truncatus and their habitat are complex, as they occur at a multitude of spatial and temporal scales. Johnson (1980) provided a distinction between studies of habitat use (the quantification of an animal's use of a habitat type in a fixed period of time) and those of habitat selection (whereby selection is proven through

*E-mail: allenmc1@aol.com the consideration of habitat availabilities in relation to their use). Animals are said to exhibit habitat selection only if they use habitats disproportionately to their availabilities. While many studies have quantified the habitat use of foraging dolphins (Shane et al. 1986), there has never been a study of habitat selection by foraging dolphins. An understanding of the patterns of animal habitat selection provides insight into the relationship between animal fitness and prey variables (Stephens \& Krebs 1986). In studying dolphin foraging, where direct interactions with prey are often unobservable, such an indirect understanding of the rela- 
tionships between dolphins and their prey is particularly valuable.

Additionally, no prior research has attempted to rigorously quantify habitat usage of foraging dolphins on a fine spatial scale. This lack of attention is surprising, as dolphin foraging (the location and pursuit of prey) and feeding (capture and handling of prey) occur over scales of $10 \mathrm{~s}$ to $100 \mathrm{~s}$ of meters. Meentemeyer \& Box (1987) proposed that any ecological study must match the spatial and temporal scale of sampling to the process being studied. If a system is studied at an inappropriate scale, the results may reflect artifacts of scale rather than salient patterns or dynamics of the system (Wiens 1989). Wiens further proposed that fine-scale studies may reveal considerable detail about biological mechanisms underlying patterns. Therefore, important interactions between dolphins and their prey may only become apparent with fine-scale studies. Finally, no studies on the foraging patterns of coastal dolphins have directly sampled prey.

Our current understanding of the relationship between bottlenose dolphins, their habitat and prey has stemmed from studies at many spatial scales. Waples (1995) documented seasonal shifts in bottlenose dolphin distribution in Sarasota Bay, Florida, from deepwater passes and channels in the winter to shallow seagrass flats in the summer. These shifts were presumed to occur in response to seasonal movements of a prey species, the striped mullet Mugil cephalus. Ballance (1992) identified high relative abundance and feeding frequencies of bottlenose dolphins near the mouth of an estuary in the Gulf of California, Mexico. Ballance proposed that the increased use of estuarine habitat relative to use of adjacent open waters was associated with increased prey abundance stemming from high estuarine biological productivity. Barco et al. (1999) linked changes in seasonal patterns in the relative abundance of bottlenose dolphins with shifts in water temperature near Virginia Beach, Virginia. The relationship between changes in relative abundance of dolphins and prey availability, if any, was unclear. Hanson \& Defran (1993), near San Diego, California, found bottlenose dolphins used structural features (i.e. nearshore reefs, offshore kelp beds) while feeding, and proposed that these patterns were associated with patterns of prey distribution and abundance.

Fine-scale studies along Florida's west coast have qualitatively described dolphin habitat use in relation to prey variables. Shane (1990a) associated bottlenose dolphin feeding-behavior with areas of abundant seagrass habitats and strong currents near Sanibel Island, Florida. Scott et al. (1996) observed that bottlenose dolphins in Sarasota Bay, Florida often fed over shallow seagrass meadows, perhaps in response to the daily movements of mullet. Analyses of stomach contents of stranded dolphins along Florida's coast have provided more quantitative information about the relationship between dolphins and their prey. Barros (1993) documented a predominance of fishes associated with seagrasses in the stomachs of inshore dolphins from the Indian River Lagoon, Florida. Barros \& Wells (1998), in studying the stomach contents of stranded dolphins in Sarasota Bay, Florida, documented the prevalence of pinfish Lagodon rhomboides, pigfish Orthopristis chrysoptera, spot Leiostomus xanthurus and striped mullet Mugil cephalus in dolphin diets. Given that these fishes are associated with seagrasses, Barros \& Wells concluded that seagrass habitat is important to the health of coastal dolphin populations. They further linked past field observations of stranded dolphins with their findings, suggesting that the relationship between dolphins and seagrass habitats is direct.

The present study was designed to quantitatively assess the fine-scale interactions between foraging dolphins, their habitat (directly) and their prey (indirectly). Based on prior studies of dolphin foraging along the west coast Florida (Shane 1990a, Scott et al. 1996, Barros \& Wells 1998), we tested the hypothesis that dolphins preferred to forage in seagrass habitats. We attempted to characterize the relative abundance of prey by sampling fishes in seagrass and nonseagrass habitats. From these field studies, a testable hypothesis of dolphin foraging strategies was developed.

\section{MATERIALS AND METHODS}

Study area. The study area consisted of 2 inshore sites located along west central Florida. Two sample sites were chosen to (1) test for similarity in patterns of habitat use by geographically distinct groups of bottlenose dolphins, and (2) assess impacts of anthropogenic influences on these patterns. Habitat types were defined by water depth $(1,2$ or $4 \mathrm{~m})$ and vegeta-

Table 1. Habitat-type descriptions and abbreviations used in text, figures and tables

\begin{tabular}{|c|c|c|c|}
\hline $\begin{array}{l}\text { Seagrass } \\
\text { present? }\end{array}$ & $\begin{array}{l}\text { Water } \\
\text { depth }\end{array}$ & Description & $\begin{array}{c}\text { Habitat } \\
\text { type }\end{array}$ \\
\hline No & $5-6 \mathrm{~m}$ & Natural channel & naCH \\
\hline No & $5-6 \mathrm{~m}$ & Dredged channel & $\mathrm{drCH}$ \\
\hline No & $0.5-1 \mathrm{~m}$ & Spoil island & SP \\
\hline No & $0.5-1 \mathrm{~m}$ & & $\mathrm{NS} 1 \mathrm{~m}$ \\
\hline No & $1-2 \mathrm{~m}$ & & $\mathrm{NS} 2 \mathrm{~m}$ \\
\hline No & $2-4 \mathrm{~m}$ & & $\mathrm{NS} 4 \mathrm{~m}$ \\
\hline Yes & $0.5-1 \mathrm{~m}$ & & $\mathrm{SG} 1 \mathrm{~m}$ \\
\hline Yes & $1-2 \mathrm{~m}$ & & $\mathrm{SG} 2 \mathrm{~m}$ \\
\hline Yes & $2-4 \mathrm{~m}$ & & $\mathrm{SG} 4 \mathrm{~m}$ \\
\hline
\end{tabular}


tion (seagrass present [SG] or no seagrass present [NS]) or anthropogenic features (dredged channels [CH] or spoil islands [SP]). Descriptions of habitat types that will be used throughout this paper are provided in Table 1.

The Anclote Key site (Fig. 1) $\left(28.14^{\circ} \mathrm{N}\right.$, $82.82^{\circ} \mathrm{W}$ ) was a relatively open embayment covering $146.6 \mathrm{~km}^{2}$. The study area extended from the shoreline west to a series of widely spaced barrier islands which provided partial protection from the Gulf of Mexico. Patchy and continuous seagrass beds, primarily Thalassia testudinum and Syringodium filiforme (Zieman \& Zieman 1989), dominated the habitat, comprising nearly $66 \%$ of the total area. Water depths within Anclote Key were 5 to $6 \mathrm{~m}$ in the passes and channels, and otherwise ranged from 1 to $4 \mathrm{~m}$ during low tide. Anclote Key had few dredged channel or spoil-island features, comprising only $2 \%$ $\left(2.82 \mathrm{~km}^{2}\right)$ of the total area, and vessel traffic was low. Anclote Key was therefore considered a relatively pristine site and exhibited a diversity of habitat types (Fig. 2).

The John's Pass site (Fig. 1) $\left(27.79^{\circ} \mathrm{N}\right.$,

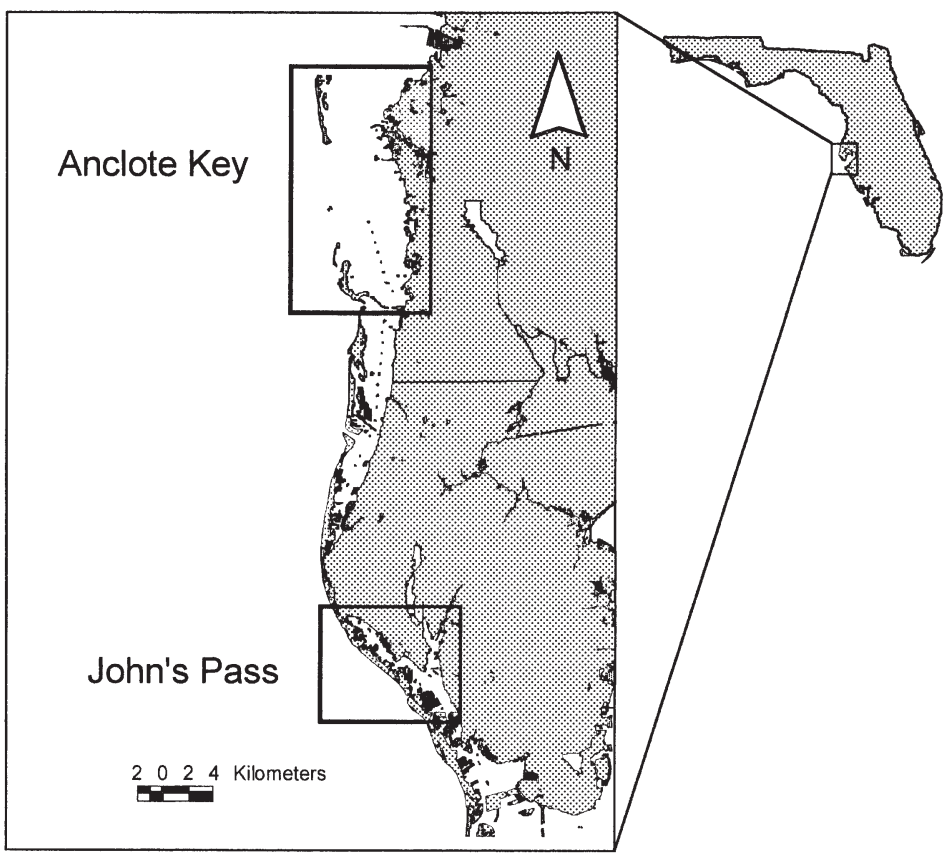

Fig. 1. Study sites Anclote Key and John's Pass, near Clearwater Harbor, Florida $\left.82.77^{\circ} \mathrm{W}\right)$ was, in contrast, a relatively constricted waterway covering only $17.2 \mathrm{~km}^{2}$. John's Pass was distinct from Anclote Key, as it was enclosed by extensive western barrier islands and the only access to the Gulf of Mexico was through a narrow pass. Seagrass was sparse, covering $4 \%\left(0.60 \mathrm{~km}^{2}\right)$ of the total area. Water depths were mostly 1 to $2 \mathrm{~m}$, with 4 to $6 \mathrm{~m}$ in the passes and channels. Anthropogenic impacts were substantial in John's Pass, with dredged channel and spoil-island habitats comprising $8 \%\left(1.4 \mathrm{~km}^{2}\right)$ of the total area and heavy vessel traffic from nearby marinas and boat rental facilities. John's Pass was considered a developed site and exhibited a relatively low diversity of habitat types (Fig. 2).

Data collection: habitat selection and behavior. Data were collected from May to August in the summers of 1997 and 1998. Tursiops truncatus were sampled using a combination of focal animal observations with instantaneous data sampling (Altmann 1974) and photo-identification (Würsig \& Würsig 1977, Würsig \& Jefferson 1990). Sampling occurred in both Anclote Key and John's Pass in the summer of 1997, but in 1998 sampling occurred exclusively at Anclote Key, as it provided a greater diversity of habitats. Sampling was conducted from 05:30 to 15:00 h.

Sites were surveyed from a $24^{\prime} 7.3 \mathrm{~m}$ outboard vessel traveling at a speed of $20 \mathrm{~km} \mathrm{~h}^{-1}$. Dolphins were located by following a route which sampled all habitat types in a direction chosen at random.

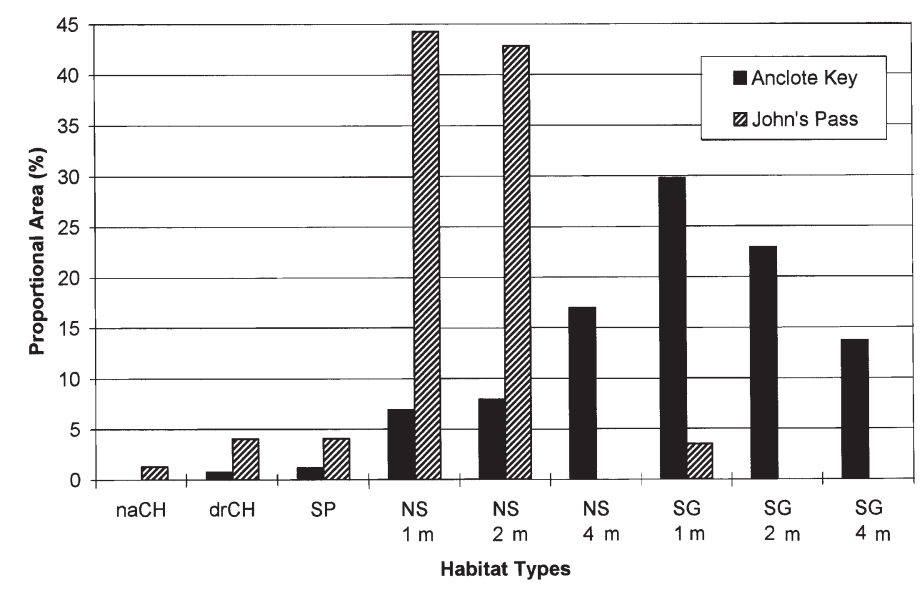

Fig. 2. Proportional area of habitat types in Anclote Key and John's Pass 
to previously followed dolphins during photo-identification were not sampled, to maximize independence of the dataset. Focal individuals were followed at a range of approximately $100 \mathrm{~m}$ (Ballance 1990). Data were recorded at 3 min intervals (Shane 1990a, Waples 1995), and consisted of the location of the focal individual, its activity, group size and group spread (all of which are defined below). All data were recorded on an Apple Newton 130 palmtop computer.

Location was determined using a Garmin GPS 120 receiver calibrated with a real-time Garmin GBR 21 Differential Beacon Receiver, which provided spatial accuracy of less than $10 \mathrm{~m}$ (Garmin Corporation 1996). The surfacing locations of focal individuals were recorded as accurately as possible (generally within $20 \mathrm{~m}$ of the actual surfacing location). Location was sampled in a staggered fashion, so that the focal individual had moved well beyond the previous surfacing (minimum of $50 \mathrm{~m}$ ) before the research vessel was moved to that location.

In the field, activity was characterized as travel, mill, feed, probable feed, social or rest using the definitions of the Sarasota Dolphin Research Program (1996). For the purposes of our analyses, activity was classified as either foraging or non-foraging. Foraging activities were identified in the field using one of the following criteria: focal individual (1) seen with fish in mouth, (2) diving deeply and rapidly presumably in pursuit of fish, (3) swirling rapidly near the surface in pursuit of fish, or (4) directly seen pursuing a fish. Due to water turbidity, the identification of foraging activity relied primarily on observations of dolphins at the surface. Therefore, potential sampling bias exists for dolphins in deeper water, where foraging activity may have occurred but was not observed (Barros \& Wells 1998).

Group size was defined as the number of dolphins (including the focal individual) within $10 \mathrm{~m}$ of the focal individual during its sampled surfacing (Connor et al. 1996). Group sizes were assigned to categories of 1, 2, 3-5, and $>5$ dolphins. Group spread was defined as the distance from the focal individual to its nearest neighbor during the sampled surfacing. Group spread was characterized by the discrete categorizations: tightly grouped (0-0.5 m), less than an average dolphin's body length $(0.5-3 \mathrm{~m})$, and greater than an average dolphin's body length $(3+\mathrm{m})$. These categorizations allowed accurate sampling in the field.

Any apparent interactions between the research vessel (or other vessels in the area) and the focal individual were recorded; these sampled intervals were not used in the analy- sis, as they were not likely to be indicative of the focal individual's natural behavior.

Data analysis: habitat selection and behavior. To account for autocorrelation between successive observations of a focal individual (Swihart \& Slade 1985) and variation in numbers of observations for each dolphin (Aebischer et al. 1993), we used individual dolphins as the fundamental sampling unit. Data derived from 1 individual over multiple sampling days were collapsed into 1 dataset. As our research question focused on dolphin foraging, we grouped observations of each individual dolphin into foraging and non-foraging datasets. A Geographic Information System (ArcView: Environmental Systems Research Institute, Inc. 1996) was used to determine patterns of habitat use for individual dolphins. Dolphin locations were overlayed on habitat maps of the Anclote Key and John's Pass study sites. As the 2 sites differed considerably in geomorphological and ecological parameters, we analyzed each site separately. A minimum of 4 data points were required for a dolphin to be considered in the analysis. This limit was derived by a power analysis comparing the variances of proportional habitat use by individual with few data points $(\mathrm{n}=1 \ldots 15)$ to individuals with many data points $(\mathrm{n}=20)$. A 2 -sample $F$-test for variances was used to identify significant differences in variances between the datasets with few and many data points (Fig. 3). Individuals with 4 data points or greater did not exhibit variances different from those of individuals with 20 data points $(F=1.952$, df $=31,23$, $\mathrm{p}<0.051$ ).

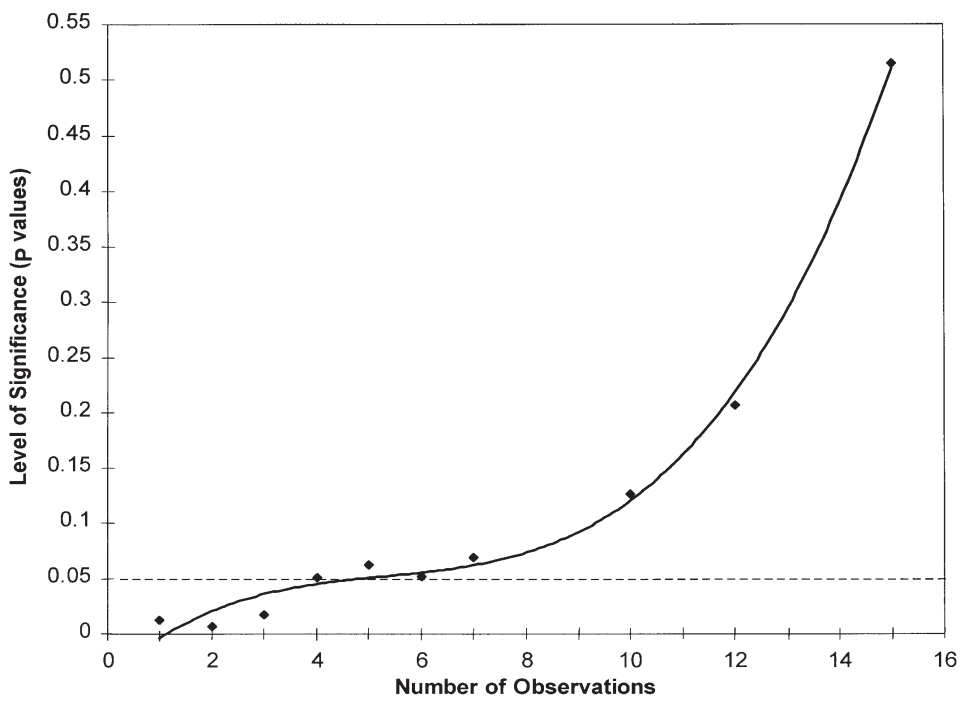

Fig. 3. Power analysis indicating minimum number of observations included in analysis. p-values result from $F$-tests comparing habitat usages of dolphins $(\mathrm{n}=1 \ldots 15$ to $\mathrm{n}=20)$ 
Bathymetry and seagrass coverages were derived from digitized maps provided by the Florida Marine Research Institute and Southwest Florida Water Management District. Bathymetry maps were 1:40000 scale, while seagrass maps were 1:24000 scale. Due to differing classification schemes imposed on the digitized seagrass maps, we were unable to consider species composition or patch characteristics in the analysis. To minimize inaccuracies in area and distance calculations, all maps were projected in Universal Transverse Mercator (Zone 17).

Habitat selection was analyzed statistically using the method of Johnson (1980), which has been shown to be robust for sample sizes and habitat diversities similar to those in our study sites (Alldredge \& Ratti 1986). A hierarchical analysis of habitat selection, as suggested by Johnson (1980) and Aebischer et al. (1993) was not feasible for this study, as the home ranges of bottlenose dolphins are often much larger than the area that can be sampled in a vessel-based study (e.g. Würsig \& Würsig 1979).

We therefore employed a technique similar to that used by Arthur et al. (1996) to quantify habitat availability for each dolphin. Habitat availability was calculated as the proportion of habitat contained within a radius of each dolphin's initial sampling point. The distance radius was calculated as a product of the duration of 1 individual's focal follow (in minutes) and the average velocity of all dolphins plus 1 standard deviation (velocities calculated as $0.817 \pm 0.433 \mathrm{~m} \mathrm{~s}^{-1}$ and $0.700 \pm 0.350 \mathrm{~m} \mathrm{~s}^{-1}$ for Anclote Key and John's Pass sites respectively). We used this metric as it provided a more biologically relevant representation of habitat available to each dolphin. This method reduces bias because (1) it does not inflate availabilities of habitats which cannot be accessed by an animal given the duration of sampling effort, and (2) it normalizes for sampling efforts which, due to either being initiated in an area of low habitat diversity or conducted over a short period of time, are not indicative of true habitat selection (Porter \& Church 1987).

For analysis of foraging activity in relation to environmental variables, we recognized the potential bias of (1) autocorrelation between successive follow observations, and (2) differing sample sizes among individuals. Therefore, each dolphin (again with 4 or more data points) was normalized (by converting numerical scores to proportions) and hence given equal consideration in the analyses. (Note: although we used individual dolphins in our analyses, we present both number of individuals and observations to reflect statistical power.)

Statistical comparisons of foraging activity were conducted using either log-likelihood ratio tests or Fisher's exact test (Sokal \& Rohlf 1995). Logistic regression was used to assess relationships between feeding frequency and time of day. Correlations were drawn between foraging frequency and categorical data using Spearman's coefficient of rank correlation (Sokal \& Rohlf 1995).

Data collection and analysis: prey. During $5 \mathrm{~d}$ in August 1998, we sampled fishes in seagrass and nonseagrass habitats, both of 3 to $4 \mathrm{~m}$ in depth, in the Anclote Key study site. We used a $3.3 \mathrm{~m}$ semi-balloon otter trawl with $4.5 \mathrm{~cm}$ mesh (Marinovich Trawl Co., Biloxi, MS, USA), towed behind a 24' (7.3 m) outboard vessel with a $225 \mathrm{hp}$ engine. Sampling was intended to provide a snapshot of fish diversity, relative abundance, and size distribution in seagrass and non-seagrass habitats. Sample sites within each habitat were selected randomly using a GIS (Geographic Information Systems) randomization routine. Each trawl was conducted for $3 \mathrm{~min}$ at a constant speed of $4 \mathrm{~km} \mathrm{~h}^{-1}$. Captured fishes were identified to species, counted, measured (standard lengths) and then released. Sampling was rotated so that each habitat was sampled during similar tidal states and times of day at similar water depths.

Rozas \& Minello (1997) identified many potential biases (e.g. inconsistent catch efficiencies for different fish species, enhanced net avoidance by larger fishes) in the use of trawl sampling to characterize fish communities. To account for these biases, comparisons were only drawn between fish of the same species captured in the 2 habitat types. Fish diversity was calculated for each trawl using the Shannon index. Mean Shannon indices were then compared statistically between habitat types using a Student's $t$-test (Sokal \& Rohlf 1995). Due to the large number of zero values present in the dataset, statistical comparisons of fishes relative abundance were made using a Wilcoxon 2-sample test (Sokal \& Rohlf 1995). Fish sizes between the 2 habitat types were compared using a Student's $t$-test (Sokal \& Rohlf 1995).

All mean values are reported with standard errors $($ mean $\pm \mathrm{SE})$.

\section{RESULTS}

\section{Habitat and environmental variables}

Over the summers of 1997 and 1998, a total of $331 \mathrm{~h}$ were spent in the field. A total of 45 individual Tursiops truncatus (1914 observations) and 22 individuals (1321 observations) were followed in Anclote Key and John's Pass sites respectively. Of these, 29 individuals (432 observations) in Anclote Key and 13 individuals (448 observations) in John's Pass were included in the analysis of habitat preference for foraging dolphins. No 
Table 2. Habitat preference of foraging and non-foraging dolphins in Anclote Key. In the summaries, >> indicates significant $(p<0.05)$ preference of habitat types to the left over all habitat types to the right; in the matrices,,+++--- indicate significant $(p<0.05)$ preference and under-utilization respectively of the habitat type to the left over the habitat type above

\begin{tabular}{|c|c|c|c|c|c|c|c|c|c|}
\hline \multicolumn{10}{|c|}{$\begin{array}{l}\text { Foraging habitat preference }\left(F_{7,22}=39.650, \mathrm{p}<0.05\right) \\
d r C H \gg>S P \gg>>N S 1 \mathrm{~m}>N S 2 \mathrm{~m}>S G 4 \mathrm{~m}>N S 4 \mathrm{~m} \gg>S G 2 \mathrm{~m} \gg>S G 1 \mathrm{~m}\end{array}$} \\
\hline & $\mathrm{drCH}$ & SP & $\mathrm{NS} 1 \mathrm{~m}$ & $\mathrm{NS} 2 \mathrm{~m}$ & $\mathrm{NS} 4 \mathrm{~m}$ & $\mathrm{SG} 1 \mathrm{~m}$ & $\mathrm{SG} 2 \mathrm{~m}$ & $\mathrm{SG} 4 \mathrm{~m}$ & Ranking \\
\hline $\mathrm{drCH}$ & & & & & & & & & 1 \\
\hline SP & --- & & & & & & & & 2 \\
\hline NS $1 \mathrm{~m}$ & --- & --- & & & & & & & 3 \\
\hline NS $2 \mathrm{~m}$ & --- & --- & - & & & & & & 4 \\
\hline $\mathrm{NS} 4 \mathrm{~m}$ & --- & --- & - & - & & & & & 6 \\
\hline $\mathrm{SG} 1 \mathrm{~m}$ & --- & --- & --- & --- & --- & & & & 8 \\
\hline $\mathrm{SG} 2 \mathrm{~m}$ & --- & --- & --- & --- & --- & +++ & & & 7 \\
\hline $\mathrm{SG} 4 \mathrm{~m}$ & --- & --- & - & - & + & +++ & +++ & & 5 \\
\hline \multicolumn{10}{|c|}{ Non-foraging habitat preference $\left(F_{7,35}=36.848, \mathrm{p}<0.05\right)$} \\
\hline & $\mathrm{drCH}$ & SP & $\mathrm{NS} 1 \mathrm{~m}$ & NS $2 \mathrm{~m}$ & NS $4 \mathrm{~m}$ & $\mathrm{SG} 1 \mathrm{~m}$ & SG $2 \mathrm{~m}$ & $\mathrm{SG} 4 \mathrm{~m}$ & Ranking \\
\hline $\mathrm{drCH}$ & & & & & & & & & 1 \\
\hline SP & --- & & & & & & & & 2 \\
\hline NS $1 \mathrm{~m}$ & --- & --- & & & & & & & 5 \\
\hline NS $2 \mathrm{~m}$ & --- & --- & + & & & & & & 3 \\
\hline NS $4 \mathrm{~m}$ & --- & --- & + & - & & & & & 4 \\
\hline $\mathrm{SG} 1 \mathrm{~m}$ & --- & --- & --- & --- & --- & & & & 8 \\
\hline $\mathrm{SG} 2 \mathrm{~m}$ & --- & --- & --- & --- & --- & +++ & & & 7 \\
\hline $\mathrm{SG} 4 \mathrm{~m}$ & --- & --- & - & - & - & +++ & +++ & & 6 \\
\hline
\end{tabular}

Table 3. Habitat preference of foraging and non-foraging dolphins in John's Pass. In the summaries, $>>>$ indicates significant $(\mathrm{p}<0.05)$ preference of habitat types to the left over all habitat types to the right; in the matrices,,+++--- indicate significant $(p<0.05)$ preference and under-utilization respectively of the habitat type to the left over the habitat type above

\begin{tabular}{|c|c|c|c|c|c|c|c|}
\hline \multicolumn{8}{|c|}{ Foraging habitat preference $\left(F_{5,8}=4.409, \mathrm{p}<0.05\right)$} \\
\hline & naCH & $\mathrm{drCH}$ & SP & NS $1 \mathrm{~m}$ & NS $2 \mathrm{~m}$ & $\mathrm{SG} 1 \mathrm{~m}$ & Ranking \\
\hline naCH & & & & & & & 1 \\
\hline $\mathrm{drCH}$ & --- & & & & & & 2 \\
\hline SP & --- & - & & & & & 6 \\
\hline NS $1 \mathrm{~m}$ & --- & - & + & & & & 5 \\
\hline NS $2 \mathrm{~m}$ & --- & - & + & + & & & 3 \\
\hline SG $1 \mathrm{~m}$ & --- & - & + & + & - & & 4 \\
\hline \multicolumn{8}{|c|}{ Non-foraging habitat preference $\left(F_{5.17}=9.011, \mathrm{p}<0.05\right)$} \\
\hline \multicolumn{8}{|c|}{$n a C H>d r C H>N S 2 m>S G 1 m>N S 1 m>S P$} \\
\hline \multicolumn{8}{|c|}{ 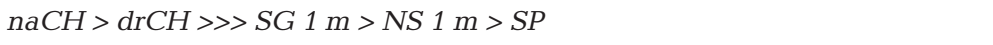 } \\
\hline & naCH & $\mathrm{drCH}$ & SP & NS $1 \mathrm{~m}$ & NS $2 \mathrm{~m}$ & $\mathrm{SG} 1 \mathrm{~m}$ & Ranking \\
\hline naCH & & & & & & & 1 \\
\hline $\mathrm{drCH}$ & + & & & & & & 2 \\
\hline SP & --- & --- & & & & & 6 \\
\hline $\mathrm{NS} 1 \mathrm{~m}$ & --- & --- & + & & & & 5 \\
\hline $\mathrm{NS} 2 \mathrm{~m}$ & --- & + & +++ & + & & & 3 \\
\hline $\mathrm{SG} 1 \mathrm{~m}$ & --- & --- & + & + & - & & 4 \\
\hline
\end{tabular}

individuals were found in both study sites.

Our first objective was to characterize the fine-scale relationship between foraging dolphins and their habitat. Dolphins engaged in foraging activity in Anclote Key exhibited significant patterns of habitat selection $(F=39.65$, df $=7,22, \mathrm{p}<0.05$ ) (Table 2). Dredged channel and spoil-island habitats were significantly preferred over all other habitat types ( $p<0.05$ ), while SG $1 \mathrm{~m}$ and SG $2 \mathrm{~m}$ habitats were least preferred ( $p<0.05)$. NS 1 m, NS 2 m, NS $4 \mathrm{~m}$ and SG $4 \mathrm{~m}$ habitats fell in the middle of the rankings. In Anclote Key, dolphins engaged in non-foraging activities exhibited similar significant patterns of habitat selection $(F=36.85$, $\mathrm{df}=7,35, \mathrm{p}<0.05$ ) (Table 2).

Foraging dolphins in John's Pass exhibited significant but less pronounced patterns of habitat selection $(F=4.41$, df $=5,8, \mathrm{p}<0.05)$ (Table 3). Only natural channel habitats were preferred significantly over all other 


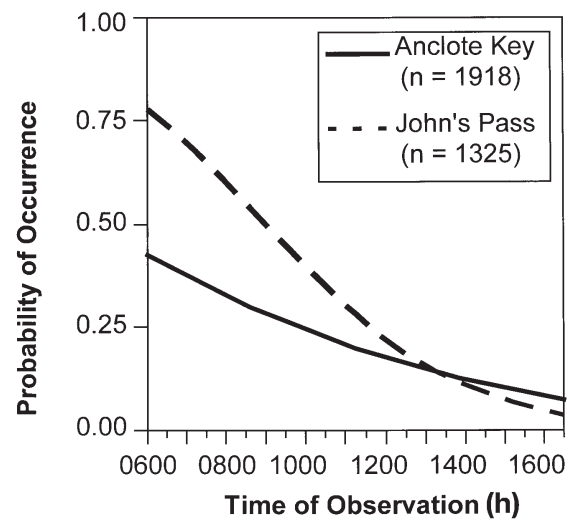

Fig. 4. Logistic regressions of foraging frequency as a function of time of day for Anclote Key and John's Pass. Lines indicate predicted probability of foraging behavior occurring at a particular time of day

habitat types $(\mathrm{p}<0.05)$; all other habitat types were statistically indistinguishable. Dolphins in John's Pass engaged in non-foraging activity showed significant preferences for natural channel and dredged channel habitats over SG $1 \mathrm{~m}, \mathrm{NS} 1 \mathrm{~m}$, and spoil-island habitats $(\mathrm{p}<0.05)(F=9.01, \mathrm{df}=5,17, \mathrm{p}<0.05)($ Table 3$)$.

Our second objective was to characterize dolphin feeding behavior in relation to environmental variables and dolphin group structure. Foraging behavior constituted $28.5 \%$ ( $\mathrm{n}=45$ individuals, 1908 observations) and $24.9 \%$ ( $\mathrm{n}=22$ individuals, 1307 observations $)$ of total observations for dolphins in Anclote Key and John's Pass respectively.

Dolphin foraging was correlated with diel states at both sites (Fig. 4). In Anclote Key, foraging activity peaked at dawn (45\%) and decreased as the day progressed $_{i}$ however, the fit of the data to the model was not strong $\left(\mathrm{n}=1918\right.$ observations; $\chi^{2}=65.354, \mathrm{r}^{2}=0.03$, $\mathrm{df}=1, \mathrm{p}<0.05)$. In John's Pass, the same patterns of foraging frequency were observed with a better fit of the data to the model ( $\mathrm{n}=1325$ observations; $\left.\chi^{2}=230.286, \mathrm{r}^{2}=0.14, \mathrm{df}=1, \mathrm{p}<0.05\right)$.

In both sites, a strong negative correlation existed between group size and feeding frequency $\left(\mathrm{r}_{\mathrm{s}}=-1.000\right.$, $\mathrm{p}<0.05$ for both sites) (Fig. 5). Further, a strong positive correlation was observed between nearest neighbor distance and dolphin feeding frequency at both sites $\left(\mathrm{r}_{\mathrm{s}}=1.000, \mathrm{p}<0.05\right)$.

\section{Fish sampling}

In Anclote Key, 49 and 59 trawls were conducted in seagrass and non-seagrass habitats respectively. Of these, 45 of 49 trawls in seagrass habitats and 19 of 59 trawls in non-seagrass yielded catch. A total of 24 and 12 fish species were caught in seagrass and non-seagrass habitats respectively. The diversity $(H)$ of fishes was less in non-seagrass $(H=0.31 \pm 0.11)$ than in seagrass $(H=1.16 \pm 0.08)$ habitats $(t=-5.049, \mathrm{df}=63$, $\mathrm{p}<0.05$ ). Pinfish dominated the catches, comprising 52 and $64 \%$ of all individuals in seagrass and nonseagrass habitats respectively. Because of the limited number of fishes captured in non-seagrass trawls ( $n=80$ ), we compared statistically only one fish species (pinfish) between habitats.

Pinfish relative abundance was an order of magnitude less in non-seagrass $\left(0.27 \pm 0.07\right.$ pinfish trawl $\left.{ }^{-1}\right)$ than in seagrass $\left(8.49 \pm 1.43\right.$ pinfish trawl $\left.{ }^{-1}\right)$ habitats $(Z=7.849, \mathrm{p}<0.05)$. Pinfish standard length was significantly greater in non-seagrass $(111.9 \pm 3.7 \mathrm{~mm})$ than in seagrass $(74.3 \pm 0.8 \mathrm{~mm})$ habitats $(t=9.978$, $\mathrm{df}=411, \mathrm{p}<0.05)($ Fig. 6) .
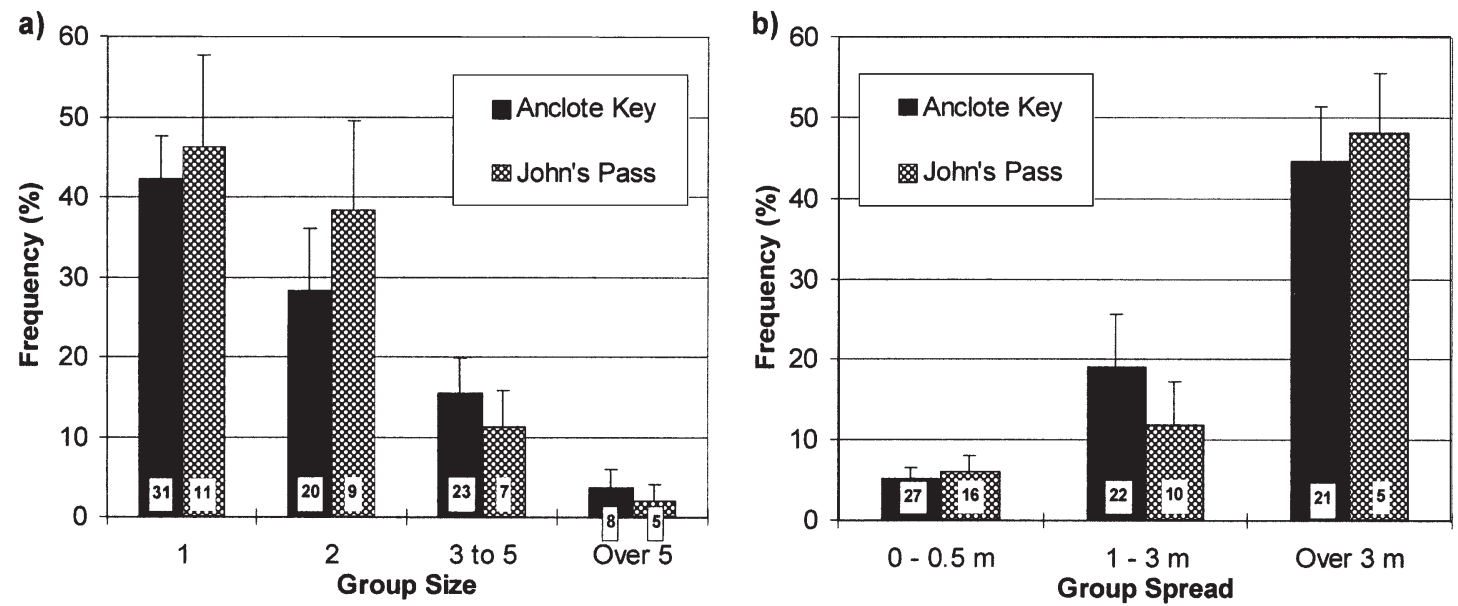

Fig. 5. Foraging frequency versus (a) group size and (b) group spread at Anclote Key and John's Pass. Sample sizes shown at base of bars 


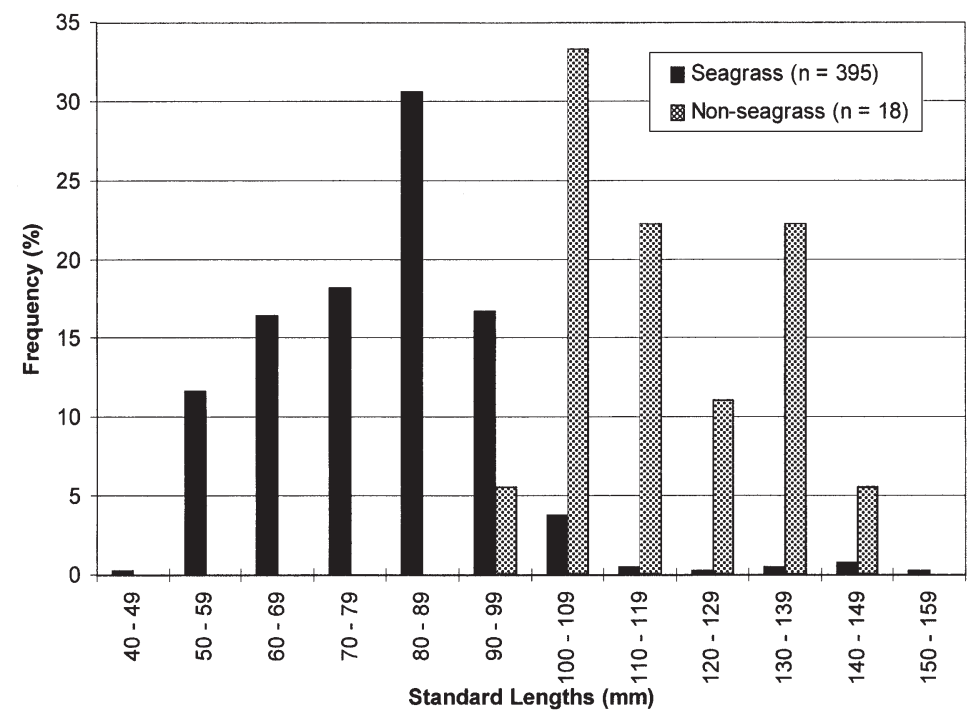

Fig. 6. Frequency distributions of pinfish standard lengths from seagrass and non-seagrass trawls

\section{DISCUSSION}

\section{Habitat selection}

Patterns of habitat selection by foraging Tursiops truncatus in both Anclote Key and John's Pass do not support the hypothesis that bottlenose dolphins feed preferentially in seagrass habitats. In Anclote Key, foraging dolphins least preferred shallow seagrass habitats and most preferred dredged channel and spoil-island habitats. In John's Pass, the only habitat preference exhibited by foraging dolphins was for natural channels.

These observations are in contrast to the conclusions of previous observations of habitat use by coastal bottlenose dolphins. Shane (1990a) found that dolphins near Sanibel Island, Florida, fed mostly in shallow water and in areas of abundant seagrasses. Scott et al. (1990) and Wells (1992) proposed that bottlenose dolphins in Sarasota Bay, Florida, feed in shallow seagrasses where mullet are present. Waples (1995), studying the same Sarasota system, concluded that dolphins fed predominantly in shallow seagrass habitats during summer months, but shifted to feeding in deep-water passes in the winter. Barros \& Wells (1998) noted that fishes associated with seagrass were common in the diet of dolphins from Sarasota.

Differences in the conclusions drawn from the present study and those described above are probably related to the different approaches used, and particularly to the scale addressed in sampling and analysis. This study is the first to: (1) employ sampling at a fine- scale; (2) derive habitat availabilities from maps of similar spatial resolution; and (3) apply habitat selection statistics. Had our scale of sampling been less resolute (e.g. recording dolphin locations with less accuracy or calculating habitat availability using coarse-scale data), we likely would have concluded that dolphins prefer seagrass habitats while foraging. Further, had we characterized habitat usage rather than habitat selection by foraging dolphins, our results would have been inconclusive.

We propose that dolphins in our study sites use structural features, such as dredged or natural channels and spoil islands, as a means of enhancing the efficiency of prey detection or capture. The use of structure during foraging has been noted for many coastal bottlenose dolphins. Shane (1990a) observed dolphins in Sanibel Island foraging frequently near bridge structures and regions of high water current. Hanson \& Defran (1993) found that Pacific coast bottlenose dolphins fed on nearshore reefs as opposed to bare sand habitats. Hoese (1971) and Petricig (1993) documented dolphins feeding on steep mud banks in tidal marshes in Georgia and South Carolina, respectively. Silber \& Fertl (1995), in the Colorado River Delta, Mexico, characterized bottlenose dolphins utilizing a sand beach as a platform on which to strand prey.

The congruency of habitat preference in both study sites between foraging and non-foraging dolphins suggests 2 possible behavioral models for dolphin habitat selection. Dolphins may prefer habitats for reasons not associated with prey, such as social behavior or predator avoidance, and simply feed when the opportunity presents itself, or dolphins may prefer habitats where they have a high probability of locating and capturing desirable prey. We cannot address the first hypothesis, as only long-term studies can characterize the influence of social behavior and predation on dolphin habitat preference. However, this study does support the hypothesis that foraging drives dolphin habitat preference.

\section{Fish data}

Our findings of greater fish diversity in seagrass than in non-seagrass habitats are well supported in the fish literature (e.g. Orth \& Heck 1980, Connolly 1994, Gray et al. 1996). The structure of submerged aquatic vegetation provides a complex habitat for both juvenile and adult fishes (e.g. Sogard et al. 1989a). The numerical dominance of pinfish in both seagrass and non-seagrass 
trawls reinforces the premise that pinfish are important in fish communities along Florida's coast. Similar trawl studies conducted in Florida Bay (Thayer \& Chester 1989), the northeast Gulf of Mexico (Jordan et al. 1997), and the Indian River lagoon, Florida (Stoner 1983), also reported pinfish as one of the most abundant fishes in both vegetated and unvegetated habitats.

We used pinfish as our comparative metric between seagrass and non-seagrass trawl data because they are one of the most abundant prey in bottlenose dolphin diets along Florida's west coast. Barros \& Wells (1998) found pinfish to dominate the diets of bottlenose dolphins in Sarasota Bay both in frequency of occurrence (56.3\%) and biomass (68.4\%). Barros \& Odell (1990), in analyzing the gut contents of stranded bottlenose dolphins along Florida's west coast, also found pinfish frequency of occurrence to be higher than other fish species. The relative abundances and size distributions of pinfish should, therefore, be an important factor in shaping habitat preference by bottlenose dolphins.

\section{Environmental variables}

Observed foraging frequencies in Anclote Key $(29 \%)$ and John's Pass (25\%) were similar to frequencies reported for other coastal dolphin communities. Using comparable methods, Shane (1990a) found feeding frequencies of $27.5 \%$ for bottlenose dolphins near Sanibel Island, Florida. Waples (1995) reported substantially lower feeding frequencies of $13 \%$ for Sarasota Bay, Florida dolphins, but suggested that her classification of feeding behavior may have been conservative. Mullin (1988), using aerial surveys, found feeding frequencies of $25 \%$ by bottlenose dolphins along the Gulf coast of Mississippi. Hanson \& Defran (1993) found Pacific coast bottlenose dolphin groups near San Diego, California, to exhibit feeding frequencies of $19 \%$.

The relationship between dolphin foraging frequency and diel state at both sites is consistent with many other behavioral studies of coastal bottlenose dolphins in North America. Bottlenose dolphins have been shown to exhibit crepuscular feeding peaks along the coasts of Florida (Shane 1990a, Waples 1995, Clement \& Morris 1998), California (Hanson \& Defran 1993, Tepper \& Defran 1995) and Texas (Shane 1990b, Bräger 1993). These feeding peaks probably reflect peaks in fish activity. Sogard et al. (1989b) in Florida Bay reported crepuscular peaks in activity for pinfish and striped mullet, both significant components of bottlenose dolphin diets along Florida's west coast (Barros \& Odell 1990, Barros \& Wells 1998).

A secondary feeding peak by dolphins in the late afternoon was not identified in our study, but this find- ing is probably an artifact of sampling. Our sampling effort was focused from dawn until mid-afternoon (approximately 15:00 h) and did not extend into late afternoon periods when daylight wanes, or into the evening or nighttime hours. Day \& Defran (1995) provided evidence that nocturnal feeding is more frequent than diurnal feeding for Pacific coast bottlenose dolphins. Therefore, foraging frequencies reported in this and other studies may not reflect the true proportion of time dolphins spend foraging over a $24 \mathrm{~h}$ period.

The results of this study indicate that coastal bottlenose dolphins feed solitarily. These results agree with previous observations of foraging toothed whales, which demonstrate that toothed whales targeting nonschooling prey tend to forage individually, while those targeting schooling prey tend to forage cooperatively (Würsig 1986). Prey of dolphins in Sarasota Bay is mostly non-schooling (pinfish, pigfish, spot) and only occasionally schooling (mullet) (Barros \& Wells 1998). Shane (1990a) in Sanibel Island concluded from both group size and group geometry that bottlenose dolphins fed individually rather than cooperatively. In general, coastal bottlenose dolphins are found in small groups while feeding in Florida (Waples 1995: 3.9 individuals), Mississippi (Mullin 1988: solitary), Texas (Shane 1990b: 3.8) and Australia (Waples \& Gales 1998: solitary).

\section{Hypothesis of dolphin foraging behavior: integration of habitat, environmental and prey variables}

Dolphins in waters of poor visibility rely heavily on acoustic sensing of their environment (Morris 1986). Studies of coastal dolphins have found evidence for both active (echolocation) and passive (listening) detection of prey. Jones \& Sayigh (1998) found low overall rates of echolocation $(2.7 \%)$ for free-ranging bottlenose dolphins in Sarasota Bay. When engaged in foraging behavior, however, dolphins echolocated in $70 \%$ of sampling intervals. Barros \& Myrberg (1987) noted the prevalence of soniferous fishes (e.g. Sciaenidae, Haemulidae) in the stomachs of stranded bottlenose dolphins in the southeastern US, and proposed that passive listening is an important component of dolphin foraging strategies. Barros \& Odell (1990) also found a predominance of soniferous fishes (Sciaenidae) in the stomachs of stranded dolphins in the Gulf of Mexico. Morris (1986) suggested that the most ecologically sensible strategy for foraging dolphins is passive listening, as dolphins would not warn their prey or alert predators by producing sound themselves.

Therefore, the availability of prey to bottlenose dolphins is likely to be a function of sound production of 
fishes and consequent detection by dolphins. All important prey of dolphins in Sarasota Bay (Barros \& Wells 1998), with the exception of mullet, produce sound (Fish \& Mowbray 1970). The true availability of these fishes to foraging dolphins, however, may be influenced by the habitats in which they reside. Seagrass habitats, although supporting greater fish abundance, may actually decrease fish availability by impairing detection by dolphins. We propose the following possible mechanisms by which this impairment could occur: (1) seagrass blades may act as baffles, attenuating fish sounds produced within the bed; (2) seagrass blades may diffuse high-energy echolocation pulses, thereby returning noisy signals to the dolphin; (3) ambient noise in the seagrass beds, arising from the prevalent acoustic activity of snapping shrimp (Knudsen 1948), may obscure fish sounds; and (4) prey may hide in the seagrass structure. Thus, it is possible that dolphins forage less frequently in habitats of structural complexity, such as seagrass meadows, because their ability to detect prey in these habitats is reduced.

The simpler structure of non-seagrass habitats, by offering fewer refuges for fishes, may increase the probability of capture and reduce pursuit time. Further, structural features such as the steep sides of channels and spoil islands may be used by dolphins to trap prey. These features may limit prey escape-responses.

Dolphins may also maximize their energetic intake by foraging in habitats where large prey occur. In Anclote Key, pinfish were significantly larger in nonseagrass than seagrass habitats. In Sarasota Bay, Florida, the average standard length of pinfish in bottlenose dolphin stomachs was $110 \pm 13.7 \mathrm{~mm}$ (Barros \& Wells 1998). This length is virtually identical to the mean length of pinfish captured in non-seagrass habitats, suggesting that dolphins may target larger pinfish in unvegetated habitats. Although seagrass habitats contain a great abundance of juvenile and small adult fishes (e.g. Livingston 1984, Sogard et al. 1989a), dolphins may not target these smaller fishes, as the energetic costs of pursuit and capture may outweigh the energetic intake. Further supporting the hypothesis of size selection, Barros \& Wells (1998) found most fishes in dolphin stomachs to be adults. Two of these fishes, pigfish and spot, exhibit ontogenetic shifts in habitat use, whereby juveniles reside in seagrass habitats and adults feed benthically (Parker 1971, Manooch 1984). Presumably then, dolphins capture adults of these species over non-seagrass habitats.

\section{Importance of seagrass habitats}

Seagrasses are critical to the health of the fish populations on which dolphins rely (Barros \& Wells 1998).
Therefore, seagrasses are indirectly important to the health of coastal dolphin populations. It is likely that the degradation of seagrasses and consequent declines in fish populations in coastal habitats would necessitate changes in the foraging strategies of dolphins.

Harris \& Kangas (1988) suggested that conservation measures for wide-ranging species (i.e. large mammals) should focus more on the scale of an animal's range (landscape) rather than subsets of an animal's range (habitats). Our study has shown the value of understanding fine-scale interactions between wideranging mammals and their habitat, and through this information we can begin to establish direct links between the health of organisms and the prey populations on which they rely. We do not regard this study as a comprehensive evaluation of questions regarding foraging dolphins and their habitats; rather, we hope that it will provide a quantitative foundation from which future hypotheses regarding fine-scale foraging strategies by dolphins may be formulated and tested.

Acknowledgements. We thank D. A. Pabst and C. T. Hackney for comments on this manuscript. We also thank the staff at the Clearwater Marine Aquarium, notably M. Baran, C. Koberna, and D. Kellenberger for their vital assistance in this research. P. Anderson, S. Diaz, J. Pierce, K. Powell, K. Snelling and J. Wourms were instrumental in assisting with data collection. This research was supported through a grant from the Taylor Foundation.

\section{LITERATURE CITED}

Aebischer NJ, Robertson PA, Kenward RE (1993) Compositional analysis of habitat use from animal radio-tracking data. Ecology 74:1313-1325

Alldredge JR, Ratti JT (1986) Comparison of some statistical techniques for analysis of resource selection. J Wild Manag 50:157-165

Altmann J (1974) Observational study of behavior: sampling methods. Behaviour 49:227-265

Arthur SM, Manly BFJ, McDonald LL, Garner GW (1996) Assessing habitat selection when availability changes. Ecology 77:215-227

Ballance LT (1990) Residence patterns, group organization, and surfacing associations of bottlenose dolphins in Kino Bay, Gulf of California, Mexico. In: Leatherwood S, Reeves RR (eds) The bottlenose dolphin. Academic Press, San Diego, p 267-283

Ballance LT (1992) Habitat use patterns and ranges of the bottlenose dolphin in the Gulf of California, Mexico. Mar Mamm Sci 8:262-274

Barco SG, Swingle WM, McLellan WA, Harris RN, Pabst DA (1999) Local abundance and distribution of bottlenose dolphins (Tursiops truncatus) in the nearshore waters of Virginia Beach, Virginia. Mar Mamm Sci 15:394-408

Barros NB (1993) Feeding ecology and foraging strategies of bottlenose dolphins on the central east coast of Florida. PhD thesis, University of Miami

Barros NB, Myrberg AA Jr (1987) Prey detection by means of passive listening in bottlenose dolphins (Tursiops truncatus). J Acoust Soc Am 62(Suppl 1):597 
Barros NB, Odell DK (1990) Food habits of bottlenose dolphins in the southeastern United States. In: Leatherwood S, Reeves RR (eds) The bottlenose dolphin. Academic Press, San Diego, p 267-283

Barros NB, Wells RS (1998) Prey and feeding patterns of resident bottlenose dolphins (Tursiops truncatus) in Sarasota Bay, Florida. J Mammal 79:1045-1059

Bräger S (1993) Diurnal and seasonal behavior patterns of bottlenose dolphins (Tursiops truncatus). Mar Mamm Sci 9:434-438

Clement DM, Morris JG (1998) Utilization of potential feeding sites by the bottlenose dolphin (Tursiops truncatus) in the Indian River Lagoon, Florida. In: Rommel SA, Reynolds JE III, Wells RS (eds) Proceedings of the Sixth Annual Atlantic Coastal Dolphin Conference. Mote Marine Laboratory \& Eckerd College, Sarasota/St. Petersburg, p 46-50

Connolly RM (1994) A comparison of fish assemblages from seagrass and unvegetated areas of a Southern Australian estuary. Aust J Mar Freshw Res 45:1033-1044

Connor RC, Richards AF, Smolker RA, Mann J (1996) Patterns of female attractiveness in Indian Ocean bottlenose dolphins. Behaviour 133:37-69

Day JR, Defran RH (1995) Nocturnal activity of Pacific coast bottlenose dolphins (Tursiops truncatus) in California. In: Abstracts -Eleventh Biennial Conference on the Biology of Marine Mammals. Society for Marine Mammalogy, Lawrence, KS, p 29

Environmental Systems Research Institute, Inc. (1996) ArcView GIS user guide. Environmental Systems Research, Institute, Inc., Redlands

Fish MP, Mowbray WH (1970) Sounds of western north Atlantic fishes. Johns Hopkins Press, Baltimore

Garmin Corporation (1996) Owner's and user's manual. Garmin Corporation, Olathe

Gray CA, McElligott DJ, Chick RC (1996) Intra- and interestuary differences in assemblages of fishes associated with shallow seagrass and bare sand. Mar Freshw Res 47: 723-735

Hanson MT, Defran RH (1993) The behaviour and feeding ecology of the Pacific coast bottlenose dolphin, Tursiops truncatus. Aquat Mamm 19:127-142

Harris LD, Kangas P (1988) Reconsideration of the habitat concept. In: McCabe RE (ed) Transactions of the 53rd North American Wildlife and Natural Resources Conference. Wildlife Management Institute, Washington DC, p 137-144

Hoese HD (1971) Dolphin feeding out of water in a salt marsh. J Mammal 52:222-223

Johnson DH (1980) The comparison of usage and availability measurements for evaluating resource preference. Ecology 61:65-71

Jones GJ, Sayigh LS (1998) Effects of activity and group size on vocal production in free-ranging bottlenose dolphins: implications for net detection. In: Abstracts - The World Marine Mammal Science Conference. Society for Marine Mammalogy and European Cetacean Society, Lawrence, $\mathrm{KS}, \mathrm{p} 69$

Jordan F, Bartolini M, Nelson C, Patterson PE, Soulen HL (1997) Risk of predation affects habitat selection by the pinfish Lagodon rhomboides (Linnaeus). J Exp Mar Biol Ecol 208:45-56

Knudsen VO (1948) Underwater ambient noise. J Mar Res 7: $410-429$

Livingston RJ (1984) The relationship of physical factors and biological response in coastal seagrass meadows. Estuaries 7:377-390

Manooch CS (1984) Fisherman's guide: fishes of the south- eastern United States. North Carolina State Museum of Natural History, Raleigh

Meentemeyer V, Box EO (1987) Scale effects in landscape studies. In: Turner MG (ed) Landscape heterogeneity and disturbance. Springer-Verlag, New York, p 15-34

Morris RJ (1986) The acoustic faculty of dolphins. In: Bryden MM, Harrison R (eds) Research on dolphins. Oxford Science Publications, Oxford, p 369-400

Mullin KD (1988) Comparative seasonal abundance and ecology of bottlenose dolphins (Tursiops truncatus) in three habitats of the North-Central Gulf of Mexico. PhD thesis, Mississippi State University

Orth RJ, Heck KL Jr (1980) Structural components of eelgrass (Zostera marina) meadows in the lower Chesapeake Bay-Fishes. Estuaries 3:278-288

Parker JC (1971) The biology of the spot, Leiostomus xanthurus Lacepede, and Atlantic croaker, Micropogon undulatus (Linnaeus), in two Gulf of Mexico nursery areas. Sea Grant Publ. TAMU-SG-71-210:1-56

Petricig RO (1993) Diel patterns of 'strand feeding' behavior by bottlenose dolphins in South Carolina salt marshes. In: Abstracts - Tenth Biennial Conference on the Biology of Marine Mammals. Society for Marine Mammalogy, Lawrence, KS, p 86

Porter WF, Church KE (1987) Effects of environmental pattern on habitat preference analysis. J Wild Manag 51: 681-685

Rozas LP, Minello TJ (1997) Estimating densities of small fishes and decapod crustaceans in shallow estuarine habitats: a review of sampling design with focus on gear selection. Estuaries 20:199-213

Sarasota Dolphin Research Program (1996) Field techniques and photo-identification. In: Proceedings of National Marine Fisheries - Southeast Fisheries of South Carolina Photo-Identification Workshop. National Marine Fisheries Service, Washington DC, p 16-22

Scott MD, Wells RS, Irvine AB (1990) A long-term study of bottlenose dolphins on the west coast of Florida. In: Leatherwood S, Reeves RR (eds) The bottlenose dolphin. Academic Press, San Diego, p 235-244

Scott MD, Wells RS, Irvine AB (1996) Long-term studies of bottlenose dolphins in Florida. IBI Rep 6:73-80

Shane SH (1990a) Behavior and ecology of the bottlenose dolphin at Sanibel Island, Florida. In: Leatherwood S, Reeves RR (eds) The bottlenose dolphin. Academic Press, San Diego, p 267-283

Shane SH (1990b) Comparison of bottlenose dolphin behavior in Texas and Florida, with a critique of methods for studying dolphin behavior. In: Leatherwood S, Reeves RR (eds) The bottlenose dolphin. Academic Press, San Diego, p 267-283

Shane SH, Wells RS, Würsig B (1986) Ecology, behavior and social organization of the bottlenose dolphin: a review. Mar Mamm Sci 2:34-63

Silber GK, Fertl D (1995) Intentional beaching by bottlenose dolphins (Tursiops truncatus) in the Colorado River Delta, Mexico. Aquat Mamm 21:183-187

Sogard SM, Powell GVN, Holmquist JG (1989a) Utilization by fishes of shallow, seagrass-covered banks in Florida Bay. 1. Species composition and spatial heterogeneity. Environ Biol Fish 24:53-65

Sogard SM, Powell GVN, Holmquist JG (1989b) Utilization by fishes of shallow, seagrass-covered banks in Florida Bay. 2. Diel and tidal patterns. Environ Biol Fish 24:81-92

Sokal RR, Rohlf FJ (1995) Biometry. The principles and practice of statistics in biological research, 3rd edn. WH Freeman \& Co, New York 
Stephens DW, Krebs JR (1986) Foraging theory. Princeton University Press, Princeton

Stoner AW (1983) Distribution of fishes in seagrass meadows: role of macrophyte biomass and species composition. Fish Bull (Wash DC) 81:837-846

Swihart RK, Slade NA (1985) Testing for independence of observations in animal movements. Ecology 66:1176-1184

Tepper EM, Defran RH (1995) Feeding duration in Pacific coast bottlenose dolphins. In: Abstracts-Eleventh Biennial Conference on the Biology of Marine Mammals. Society for Marine Mammalogy, Lawrence, KS, p 113

Thayer GW, Chester AJ (1989) Distribution and abundance of fishes among basin and channel habitats in Florida Bay. Bull Mar Sci 44:200-219

Waples DM (1995) Activity budgets of free-ranging bottlenose dolphins (Tursiops truncatus) in Sarasota Bay, Florida. Master's thesis, University of California Santa Cruz

Waples KA, Gales NJ (1998) The social ecology of a coastal population of bottlenose dolphins in western Australia. In: Abstracts - The World Marine Mammal Science Conference. Society for Marine Mammalogy and European Cetacean Society, Lawrence, KS, p 145

Wells RS (1992) The marine mammals of Sarasota Bay. In:

Editorial responsibility: Otto Kinne (Editor),

Oldendorf/Luhe, Germany
Sarasota Bay National Estuary Program (ed) Sarasota Bay: 1992 framework for action. National Estuary Program, Sarasota, p 9.1-9.23

Wiens JA (1989) Spatial scaling in ecology. Funct Ecol 3: 385-397

Würsig B (1986) Delphinid foraging strategies. In: Schusterman R, Thomas J, Wood FG (eds) Dolphin cognition and behavior. Lawrence Erlbaum Associates, Hillsdale, p $347-359$

Würsig B, Jefferson TA (1990) Methods of photo-identification for small cetaceans. In: Donovan GP (ed) Report of the International Whaling Commission. Special Issue No. 12. International Whaling Commission, Cambridge, p 43-55

Würsig B, Würsig M (1977) The photographic determination of group size, composition, and stability of coastal porpoises (Tursiops truncatus). Science 18:755-756

Würsig B, Würsig M (1979) Behavior and ecology of the bottlenose dolphin, Tursiops truncatus, in the south Atlantic. Fish Bull (Wash DC) 77:399-412

Zieman JC, Zieman RT (1989) The ecology of the seagrass meadows of the west coast of Florida: a community profile. United States Department of the Interior Fish and Wildlife Service, Washington, DC

Submitted: November 11, 1999; Accepted: October 26, 2000 Proofs received from author(s): October 16, 2001 